ACCEPTED MANUSCRIPT

\title{
Silk fibroin/amniotic membrane 3D bi-layered artificial skin
}

To cite this article before publication: Mazaher Gholipourmalekabadi et al 2017 Biomed. Mater. in press https://doi.org/10.1088/1748$\underline{605 X / a a 999 b}$

\section{Manuscript version: Accepted Manuscript}

Accepted Manuscript is "the version of the article accepted for publication including all changes made as a result of the peer review process, and which may also include the addition to the article by IOP Publishing of a header, an article ID, a cover sheet and/or an 'Accepted Manuscript' watermark, but excluding any other editing, typesetting or other changes made by IOP Publishing and/or its licensors"

This Accepted Manuscript is () 2017 IOP Publishing Ltd.

During the embargo period (the 12 month period from the publication of the Version of Record of this article), the Accepted Manuscript is fully protected by copyright and cannot be reused or reposted elsewhere.

As the Version of Record of this article is going to be / has been published on a subscription basis, this Accepted Manuscript is available for reuse under a CC BY-NC-ND 3.0 licence after the 12 month embargo period.

After the embargo period, everyone is permitted to use copy and redistribute this article for non-commercial purposes only, provided that they adhere to all the terms of the licence https://creativecommons.org/licences/by-nc-nd/3.0

Although reasonable endeavours have been taken to obtain all necessary permissions from third parties to include their copyrighted content within this article, their full citation and copyright line may not be present in this Accepted Manuscript version. Before using any content from this article, please refer to the Version of Record on IOPscience once published for full citation and copyright details, as permissions will likely be required. All third party content is fully copyright protected, unless specifically stated otherwise in the figure caption in the Version of Record.

View the article online for updates and enhancements. 


\title{
Silk Fibroin/Amniotic Membrane 3D Bi-layered Artificial Skin
}

\author{
Mazaher Gholipourmalekabadi ${ }^{1,2}$, Ali Samadikuchaksaraei ${ }^{1,2}$, Alexander M. Seifalian ${ }^{3}$,
} Aleksandra M. Urbanska ${ }^{4}$,Hossein Ghanbarian ${ }^{5,6}$, John G. Hardy ${ }^{7,8}$, Mir Davood Omrani ${ }^{9}$, Masoud Mozafari ${ }^{1,2,10}$, Rui L. Reis ${ }^{11}$, Subhas C. Kundu ${ }^{11}$

${ }^{1}$ Cellular and Molecular Research Centre and ${ }^{2}$ Department of Tissue Engineering \& Regenerative Medicine, Faculty of Advanced Technologies in Medicine, Iran University of Medical Sciences, Tehran, Iran.

${ }^{3}$ Nanotechnology and Regenerative Medicine Commercialisation centre (Ltd), The London BioScience Innovation Centre, London, UK

${ }^{4}$ Division of Digestive and Liver Disease, Department of Medicine and Herbert Irving Comprehensive Cancer Center, Columbia University, New York, USA.

${ }^{5}$ Cellular \& Molecular Biology Research Centre and ${ }^{6}$ Biotechnology Department, Faculty of Medicine, Shahid Beheshti University of Medical Science (SBUMS), Tehran, Iran.

${ }^{7}$ Department of Chemistry and ${ }^{8}$ Materials Science Institute, Lancaster, Lancashire, UK

${ }^{9}$ Department of Medical Genetics, Faculty of Medicine, SBUMS, Tehran, Iran.

${ }^{10}$ Nanotechnology and Advanced Materials Department, Materials and Energy Research Center, Tehran, Iran.

${ }^{11} 3$ Bs Research Group, Headquarters of the European Institute of Excellence on Tissue Engineering and Regenerative Medicine, University of Minho, Guimaraes, Portugal.

\section{*Corresponding authors:}

Alexander M. Seifalian, Director / Professor of Nanotechnology and Regenerative Medicine Emaila.seifalian@gmail.com, Tel: +44 7985380797

Dr. Mazaher Gholipourmalekabadi, PhD of Medical Biotechnology

Tel: (+98 21) 8862 2755; Fax: (+98 21) 88622533

Email:mazaher.gholipour@gmail.com 


\section{Abstract}

Burn injury has been reported to be an important cause of morbidity and mortality and it is still considered as unmet clinical need. Although there is a myriad of effective stem cells suggested for skin regeneration, there is no one ideal scaffold. The aim of this study was to develop a 3D bi-layer scaffold made of biological decellularised human amniotic membrane (AM) with viscoelastic electrospun nanofibrous silk fibroin (ESF) spun on top. The fabricated 3D bi-layer $\mathrm{AM} / \mathrm{ESF}$ scaffold was submerged in ethanol to induce $\beta$-sheet transformation as well as to get a tightly coated and inseparable bilayer. The biomechanical and biological properties of the 3D bilayer AM/ESF scaffold were investigated. The results indicate a significant improved mechanical properties of the AM/ESF compared to the AM alone. Both AM and AM/ESF possess a variety of suitable adhesion cells without detectable cytotoxicity against the Adipose Tissue-Derived Mesenchymal Stem Cells (AT-MSCs). The AT-MSCs show increased expression of two main pro-angiogenesis factors VEGFa and bFGF when cultured on the AM/ESF for 7 days in comparison with AM alone. The results suggest that AM/ESF scaffold with autologous ATMSCs has excellent cell adhesion and proliferation along with production of growth factors which serves as a possible application in clinical setting in skin regeneration.

Keywords: Scaffold; Human amniotic membrane; silk fibroin; biomaterial; skin substitute. 


\section{Introduction}

Full-thickness skin wounds, especially caused by $3^{\text {rd }}$ degree burns with more than $10 \mathrm{~mm}$ in diameter, require skin grafting to fully heal and prevent related complications [1, 2]. Many attempts are made to develop an ideal skin substitute that would accelerate wound healing and prevent infections. An ideal skin substitute should have mechanical properties similar to normal skin, facilitate cell attachment, proliferation, migration and differentiation, degrade in a comparable rate to the formation of new skin, and prevent infections $[1,3-5]$. To date, there is no such product; however there is a number of scaffold materials, such as decellularised bovine collagen based membrane (Intergra ${ }^{\mathrm{TM}}$ ), silicon-based sheets and decellularised human amniotic membrane (AM) which can serve as next best substitutes. Unfortunately, these materials are quite expensive, hence skin regeneration is considered as unmet clinical need [1]. For instance, AM is used in the management of burn wounds today [6].

AM is a natural bio-scaffold and has many favourable characteristics for use as skin substitute including high elasticity, structural integrity, ECM composition similar to human skin, antiscaring effect, supportive effects on cell migration, proliferation, differentiation and antibacterial activity. These properties make this membrane a promising and optimal skin substitute [6-10]. It is reported that epithelial and mesenchymal layers of the AM have anti-angiogenic and angiogenic properties. Despite all the unique characteristics of AM as a wound dressing, its weak mechanical properties and fast degradation remain a challenge. Wet AM is hardly handled during the grafting and degraded before the wounds fully heal [11]. Table 1 shows the recent research work on skin regeneration for wound healing applications.

Please insert Table 1 here 
In this work, we hypothesize to overcome the disadvantages associated with AM grafting by multilayer coating it with natural and optimal biomaterial such as nanofibrous silk protein. Silk has favourable characteristics such as aqueous preparation, superior mechanical properties, suitable elasticity, adequate angiogenicity and slow biodegradability. Silk fibroin of Bombyx mori mulberry silkworm is a cyto-biocompatible and extensively used in tissue engineering applications. [12-18]. A number of silk containing products are used in plastic surgery applications, which are approved by FDA [19].

In this paper, we report the fabrication and characterization of bi-layer membranes made from decellularised human amniotic membrane (AM) and Electrospun Nanofibrous Silk Fibroin (ESF). Our bi-layer artificial skin substitute showed an improved angionenesis in in vitro evaluation by increased expression of angiogenic factors in adipose tissue-derived mesenchymal stem cells (AT-MSCs) when compared to AM. Our improved bi-layer artificial skin scaffold presents an excellent option as a skin substitute and mesenchymal stem cells carrier for skin tissue engineering applications.

\section{Materials and Methods}

\subsection{Fabrication of bi-layer decellularised human amniotic membrane and electrospun} nanofibrous silk fibroin

\subsubsection{Human amniotic membrane}

The AM samples were obtained and decellularised by a simple and cost-effective method as previously described [11]. Briefly, the human placentas were obtained from consenting mothers upon cesarean sections under sterile conditions. The samples were screened to be negative for 
the following agents: the human immunodeficiency virus type II, syphilis, gonorrhea, human hepatitis virus types B and C, toxoplasmosis and cytomegalovirus. The AM was separated from chorion and then treated with $0.2 \%$ EDTA and $0.5 \mathrm{M} \mathrm{NaOH}$ and scraped to remove the cells. The sample collection and experiments were performed in accordance with the World Medical Association Declaration Of Helsinki [20]. The decellularisation of the membrane was confirmed by immunohistochemistry (IHC) and H\&E staining. The decellularised membrane was dried under vacuum and sterilized by gamma irradiation.

\subsubsection{Preparation of nanofibrous silk protein fibroin by electrospinning}

\subsubsection{Extraction and purification}

The extraction and purification of silk fibroin from cocoons of Bombyx mori mulberry silkworm were carried out as described previously [21]. Briefly, the cocoons were boiled at $100^{\circ} \mathrm{C}$ in an aqueous solution of $0.02 \mathrm{M}$ sodium bicarbonate $\left(\mathrm{Na}_{2} \mathrm{CO}_{3}\right)$ and the fibres were thoroughly rinsed with deionized water to remove the glue-like silk protein sericin. The degummed silk fibbers were dissolved in 9.3 M Lithium bromide $(\mathrm{LiBr})$ solution at $60^{\circ} \mathrm{C}$ for 4 hours and samples were dialyzed (MWCOs of $12 \mathrm{KDa}$ ) against ultrapure water with changes every 2 hours. The dialyzed fibroin solution was lyophilized and stored at room temperature until future use.

\subsubsection{Nuclear magnetic resonance (NMR) analysis}

The extracted and dried SF powder was characterized by a high resolution ${ }^{13} \mathrm{C}$ NMR spectra (FTNMR (600 MHz) AVANCE 600, Bruker, Germany). The SF powder was dissolved in formic acid (FA) (10\% w/v) and subjected to NMR analysis as described previously [22]. 


\subsubsection{Fourier transform infrared (FTIR) spectroscopy}

Methanol and ethanol are the most common solvents for induction of water insoluble $\beta$-sheet conformational transition [23-25]. The SF was treated with $70 \%$ ethanol for 1 hour. The molecular conformation of the SF was determined by FTIR spectroscopy ( 55 FTIR EQUINOX spectrophotometer, BrukerOptik GmbH, Germany). For this purpose, before and after ethanol treatment, the dried SF powder was mixed with potassium bromide (KBr) and analysed in the spectral region of 4000-400 cm-1 with a resolution of $4 \mathrm{~cm}^{-1}[26]$.

\subsubsection{Fabrication of AM/ESF bi-layered membrane}

$10 \%$ Silk fibroin (SF) solution in formic acid (FA) was prepared as described in our previously published study [21]. For electrospinning, AM membrane $(20 \times 3 \mathrm{~cm})$ was fixed to drum covered with an aluminium foil. The SF/formic acid solution in a 3-mL syringe was electrospun on the dried AM. The electrospinning was performed under the following conditions: A voltage of $18 \mathrm{kV} / \mathrm{cm}, 15 \mathrm{~cm}$ distance between the syringe and the collector and $0.3 \mathrm{~mL} / \mathrm{H}$ constant flow rate. In this study, the SF solution was electrospun for 20 minutes (this confirmed the attachment of ESF to AM) and $3 \mathrm{~h}$ (this finalized AM/ESF bi-layer membrane). AM/ESF was treated with $70 \%$ ethanol for 1 hour and subsequently dried under vacuum. Ethanol treatment was also done on AM alone following same procedure. The synthesized bi-layer membrane was kept in $4 \mathrm{C}$ until further use. The schematic of bi-layer skin scaffold preparation is illustrated in Figure 1.

\section{Please insert Figure 1 here}




\subsection{Biological and cellular characterization}

\subsubsection{Surface characterization using SEM}

After 20 min and 3 hours of electrospinning the AM and AM/ESF with gold, their morphologies were observed under scanning electron microscope (SEM, Philips XL30, Netherlands) at an acceleration voltage of $15 \mathrm{kV}$. The average diameter of the spun nano-fibers $(n=10)$ before and after ethanol treatment were determined by SEM software and analysed.

\subsubsection{Biomechanical behaviour}

A universal tensile strength testing machine at a crosshead speed of $10 \mathrm{~mm} \cdot \mathrm{min}^{-1}$ with a specified sample size (length $=20 \mathrm{~mm}$ and width $=10 \mathrm{~mm}$ ) was used to evaluate the biomechanical behaviour of the AM and AM/ESF $(n=5)$. Maximum load value $(N)$, suture retention strength $(\mathrm{mN})(5-0$ nylon suture) and strain deflection at break $(\mathrm{mm})$ of the AM/ESF were determined by a protocol previously described and compared to those of AM alone [11]. Mitutoyo 547-400S Digimatic IDC thickness gauge was used for a measurement of average thickness.

\subsubsection{Biodegradation}

The degradation properties of the AM/ESF were determined by enzymatic reaction, namely 0.1 wt \% solution of lysozyme in DMEM culture medium with addition of PBS solutions in vitro, as described previously with few modifications [11]. Briefly, the samples were weighed $\left(\mathrm{m}_{0}\right)$ and embedded into $10 \mathrm{ml}$ of degradation solution (PBS or enzyme). All the samples were incubated at $37^{\circ} \mathrm{C}$ for 14 days. 3 samples were removed after each predetermined incubation time, washed 
with distilled water and dried at room temperature for 72 hours. The samples were weighed $\left(\mathrm{m}_{\mathrm{d}}\right)$ and percentage of weight loss was determined by the following formula;

$$
\text { Weight loss }(\%)=\frac{m_{0}-m_{d}}{m_{0}} \times 100
$$

\subsubsection{Adipose tissue-derived mesenchymal stem cells responses to AM/ESF \\ 2.2.4.1. The adipose tissue-derived mesenchymal stem cells isolation and expansion}

The AT-MSCs were isolated from inguinal fat pads of BALB/C mice according to procedures approved by the Ethics Committee of the Medical Sciences. The isolation protocol is described in detail elsewhere $[8,27]$. Briefly, $10 \mathrm{~g}$ of the adipose tissue was collected and mixed with $0.2 \%$ collagenase II (Sigma, St. Louis, MO, USA) for $30 \mathrm{~min}$ at $37^{\circ} \mathrm{C}$ under sterile conditions. The samples were centrifuged at $2500 \mathrm{rpm}$ for $10 \mathrm{~min}$. The supernatant was removed and the pellet was resuspended in DMEM (Dulbecco's Modified Eagle Medium) supplemented with 10\%FBS 1\% pen/strep, nystatin and amphotericin B, $2 \mathrm{mM}$ Glutamax, $1 \mathrm{mM}$ L-glutamine and 1\% nonessential amino acids (all from Gibco, Carlsbad, CA, USA). The cells were harvested in two 75$\mathrm{cm}^{2}$ flasks. The number of viable cells/was assessed based on $0.4 \%$ trypan blue exclusion (Sigma-Aldrich, USA) method.

\subsubsection{Characterization of adipose tissue-derived mesenchymal stem cells (AT-MSCs)}

The AT-MSCs were characterized by flow cytometry. The cells were examined for the expression of CD34, CD44, CD45, CD73, CD90 and CD105. The AT-MSCs with density of 3 $\times 10^{5} / 100 \mu \mathrm{l}$ were incubated with antibodies in the dark chamber for $30 \mathrm{~min}$ at $37^{\circ} \mathrm{C}$. The cells were then washed and analysed by flow cytometry as described previously [28]. The AT-MSCs were further characterized for their differentiation capacity towards osteogenic and adipogenic 


\subsubsection{Cell adhesion and distribution}

lineages $[29,30]$. First the cells were treated with osteogenic differentiation media for three weeks and then stained with Alizarin-red (Sigma-Aldrich, USA) to visualize mineralized matrix. Next, the cells were treated with adipogenic differentiation media for three weeks and then stained with Oil-red (Sigma-Aldrich, USA). The stained cells were viewed and images taken under light microscope.

For cell adhesion and distribution studies, the cells were seeded on the membranes $(1 \times 1 \mathrm{~cm})$ and incubated for 72 hours. The morphology of the cells cultured on the samples was observed under SEM [11]. The cells were also stained with 4,6-diamidino-2-phenylindle (DAPI) [31] to analyze the cell density along the scaffold. For quantitative analysis, the DAPI stained samples were viewed under fluorescent microscope and the cells were counted from 10 different areas $(100 \times$ magnification). The test was repeated three time and the average of cell count was reported as cell density.

\subsubsection{Long-term cell viability and cytotoxicity}

The AT-MSCs viability and cytotoxicity were evaluated by MTT and LDH specific activity, as described previously [8]. Briefly, the cells $\left(1 \times 10^{4}\right.$ cells/well $)$ were cultured on the membranes $(1 \times 1 \mathrm{~cm})$ for $1,5,10$ and 15 days in a cell culture incubator $(\mathrm{n}=3)$. After each time interval, the media were collected and subjected to LDH specific activity assay using a LDH kit (Zist Shimi kits, Tehran, Iran) [8]. For cell viability assay, the cells after were treated with $10 \%$ MTT solution for $1 \mathrm{~h}$ and then embedded in dmethyl sulfoxide (DMSO) for $20 \mathrm{~min}$. The optical 
density (OD) of the samples was measured using an enzyme-linked immunosorbent assay (ELISA) reader at a wavelength of $590 \mathrm{~nm}$. The viability of the AT-MSCs cultured on plastic surface of cell culture plate was considered as positive control (100\% cell viability). Sterile cell culture media with no cells or membrane served as negative control (ODnc). The cell viability was determined by the following formula;

$$
\text { AbsorbanceValue }=O D s-O D n c
$$

\subsection{Angiogenesis}

To determine whether the AM/ESF may accelerate post-injury neovascularization, the effects of $\mathrm{AM} / \mathrm{ESF} / \mathrm{AT}-\mathrm{MSCs}$ cross-talk on secretion of the pro-angiogenic factors such as VEGF and bFGF from these cells were evaluated in vitro. For this, the AT-MSCs were seeded on the decellularised $\mathrm{AM}$ and $\mathrm{AM} / \mathrm{ESF}$ membrane and incubated at 5\% $\mathrm{CO}_{2}$ and $95 \%$ air for 7 days. The cells cultured on tissue culture plate served as control. After specified time, the cells were evaluated for their expression of VEGFa and bFGF in vitro by real-time PCR and immunostaining IF? [32].

\subsubsection{Real-time PCR}

The total RNA was extracted by RNX-Trizol reagent according to the manufacturer's protocol (Cinagen, Tehran, Iran). Transcription of $0.1 \mu \mathrm{g}$ RNA to cDNA was performed by a HighCapacity cDNA Archive kit using random hexamer primer according to the supplier's instructions (Applied Biosystems, Foster City, CA, USA). The relative expressions of vascular endothelial growth factor (VEGFa) and basic fibroblast growth factor (bFGF) were determined by RT-PCR (rotor-gene 6000, Corbett Life Science, Sydney, Australia) using PCR Master Mix 
(TaKaRa, Dalian, China). The expression level of each target gene was normalized against betaactin (b-actin) gene. The relative expression was defined based on $2^{-\Delta \Delta C t}$. All the primers used in this study and the product lengths are listed in Table 1.

\section{Please insert Table 1 here}

\subsubsection{Immunostaining}

For immunostaining, the cells were washed with phosphate buffer saline (PBS) twice and fixed with 4\% paraformaldehyde (PFA) for $30 \mathrm{~min}$. After permeabilisation of the cells with $0.025 \%$ Triton X-100 and washing with PBS, the nonspecific binding was blocked by treatment of the cells with $10 \%$ goat serum for $30 \mathrm{~min}$. The cells were then treated with primary antibodies antiVEGFa and anti-bFGF for $1 \mathrm{~h}$ at $37^{\circ} \mathrm{C}$. The FITC-conjugated goat polyclonal antibody to Rabbit IgG was used as secondary antibody [33]. All the antibodies were purchased from Abcam, Cambridge, MA, USA. The counter stain was performed using DAPI. The positive cells for VEGFa and bFGF were counted under fluorescent microscope (Olympus BX51, Japan) and the results were reported as average cell number per high-power field (HPF).

\subsubsection{Statistical analysis}

The results were analysed by Student's t -tests One-way ANOVA and Turkey test. The analysis was performed using SPSS software (Version 16, SPSS Inc., Chicago, IL, USA). Statistical analysis was carried out by applying One-way ANOVA and Turkey test. The $\mathrm{P}<0.05$ was set as level of significance. 


\section{Results and Discussion}

\subsection{Human amniotic membrane (AM)}

The decellularisation of the AM was described previously [11]. The complete removal of the cells and cellular debris was confirmed using dead and live staining, H\&E staining and DNA assay. It was also confirmed that the decellularisation did not affect the ECM of the AM using IHC staining as described in our previous studies [8, 11]. It is generally known that the graft rejection limits the use of $\mathrm{AM}$ as an allograph. Denudation of the AM may improve cell proliferation along with decreased immunogenicity $[11,34]$.

\subsection{Silk fibroin (SF) characterization}

\subsubsection{NMR}

The results obtained from ${ }^{13} \mathrm{C}$-NMR spectra of the regenerated SF are illustrated in Fig. 2a and 2b. The distinctive peaks appeared at $16.9 \mathrm{ppm}$ (C $\beta$ of Ala), 43.1 (C $\alpha$ of Gly) and 50.2 (C $\alpha$ of Ala) of the SF/formic acid solution. The secondary structure of SF molecules in solution can be determined by $\mathrm{C} \beta$ (Ala) chemical shift. The random coil (Structure III) and $\beta$-sheet conformation (Structure II) display different peaks at 16.9 and $19.5 \mathrm{ppm}$, respectively [22]. According to the NMR spectra, C $\beta$ (Ala) chemical peak was at $16.9 \mathrm{ppm}$, indicating random coil structure of SF in FA. This is similar to aqueous SF solution.

\section{Please insert Figure 2 here}

\subsubsection{FTIR}

The induced insoluble $\beta$-sheet conformational transition of the SF was confirmed by FTIR spectroscopy $[23,25]$. The infrared spectra of the SF before and after ethanol treatment are 
depicted in Figure 2c. The FTIR spectra results of the ethanol-treated SF showed characteristic peaks of $ß$-sheet conformation at $1636 \mathrm{~cm}^{-1}, 1516 \mathrm{~cm}^{-1}, 1235 \mathrm{~cm}^{-1}$ and $965 \mathrm{~cm}^{-1}$ with no changes in $\alpha$-helix characteristic peaks $\left(621 \mathrm{~cm}^{-1}\right)[23,26]$.

\subsection{Human amniotic membrane/electrospun nanofibrous silk fibroin (AM/ESF)} characterization

\subsubsection{Morphology}

The morphology of the AM/ESF was observed under SEM after $20 \mathrm{~min}$ and $3 \mathrm{~h}$ electrospinning (Fig. 3a). The silk fibroin (10\%) nano-fibers were successfully electrospun and arranged in a specific orientation as displayed by SEM micrographs. They were homogenous throughout with no beaded fibres. In 20 min electrospun samples, the attachment of the SF nano-fibers to the AM is clearly observed after ethanol treatment. After alcohol treatment, ESF was tightly coated and ensured non separation of the AM. The average diameters of the spun nano-fibers before and after ethanol treatment were $93 \pm 25 \mathrm{~nm}$ and $157 \pm 32 \mathrm{~nm}$, respectively (Fig. 3b). The results are consistent with previously published report [21]. The tilt view SEM image of the AM/ESF (Fig. 3a) confirmed the coating of the AM by ESF.

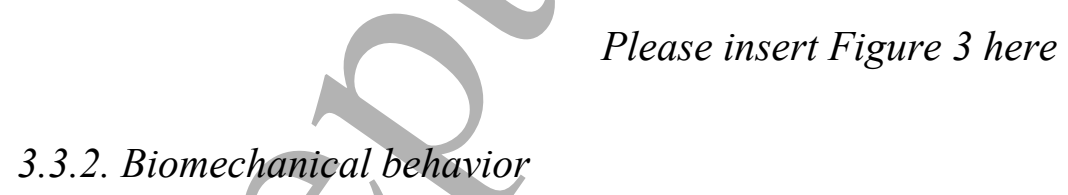

The effects of the SF electrospinning on the mechanical behaviors of the AM/ESF are summarized in Table 2. The AM/ESF showed significantly improved mechanical properties including maximum load value, suture retention strength, strain deflection at break and thickness when compared with AM samples. Tissue engineering scaffolds must provide sufficient 
biomechanical properties for better regeneration of damaged tissues. In our previous study [23], we showed that ethanol treatment and subsequently $\beta$-sheet structure formation of ESF significantly increase its mechanical behaviours. Vasconcelos et al. [35] fabricated a 3D silk fibroin/elastin wound dressing with excellent chemical and mechanical properties for biological applications. The biomechanical properties of AM/ESF were comparable with other skin substitutes using waxes, chondroitin sulfate/hyaluronic acid [14, 36]. For example, Kanokpanont and colleagues showed that coating SF fabric with wax increase its biomechanical properties with no cytotoxicity effects [14]. Insufficient mechanical property of AM makes it difficult for grafting. To address this issue, the researchers are attempting to find a way to enhance biomechanical behaviour of AM without affecting its cell adhesion and non-cytotoxicity properties. For example, cross-linking of AM with carbodiimide and glutaraldehyde successfully enhanced its biomechanical behaviour. Negative effects of such agents on structure, molecular stability and cytocompatibility of AM were demonstrated previously [37, 38]. The biomechanical testing of this study indicates that the coating the AM with ESF significantly increases its mechanical properties and may makes it an excellent 3D skin substitute for skin tissue engineering applications.

\subsubsection{In vitro degradation of $A M / E S F$}

Please insert Table 2 here

The degradation rate of scaffolds for tissue engineering purpose is very critical and can profoundly affect healing effectiveness. Quick degradation of biomaterial causes the scaffold to disintegrate too early before healing of the damaged tissue is complete. The in vitro degradation rates of the engineered functional materials (AM and AM/ESF) were determined by treatment with PBS (Fig. 4a) and lysozyme (Fig. 4b) solution for 14 days. The degradation rate of the 


\section{Please insert Figure 4}

\subsubsection{The adipose tissue-derived mesenchymal stem cells responses on AM/ESF}

\subsubsection{Characterization of adipose tissue-derived mesenchymal stem cells (AT-MSCs)}

According to the results obtained from the flow cytometry, $69.6 \%, 96.8 \%, 76.5 \%$ and $94.4 \%$ of the cell population were positive for CD44, CD73, CD90 and CD105, respectively (Fig. 5a). Only $2.72 \%$ and $3.56 \%$ of the cells were positive for CD34 and CD45, respectively. The 
Alizarin-red and Oil-red staining confirmed that the cells were successfully differentiated into both osteogenic and adipogenic lineages (Fig. 5b) [27, 29, 42].

Please insert Figure 5 here

\subsubsection{Cell adhesion and distribution}

Interaction of the cells with surface of biomaterials profoundly affects various cell behavior such as adhesion, proliferation and differentiation. These properties strongly depend on the physicochemical characteristics and hydrophilicity of the materials [43]. Therefore, cell adhesion of tissue engineering scaffolds is of critical importance. The morphologies of the AT-MSCs cultured on the AM/ESF before and after ethanol treatment were analyzed by SEM (Fig. 6a). The spindle morphology of the AT-MSCs on all the samples was clearly observed at day 3 postseeding. The conformation of the AT-MSCs with the surface of the membranes clearly represented the effective cell-substrate attachment. The elongated morphology of the cells as well as their filopodia-like membrane suggests that all the membranes are suitable for cellular adhesion and proliferation. Moreover, DAPI staining was performed to determine the density and distribution of the AT-MSCs on the membranes (Fig. 6c). No significant difference was observed between the samples $(\mathrm{p}>0.05)$ in the cell density. These results are consistent with earlier investigations $[8,29,44]$ which showed a high attachment of both silk fibroin and collagen to L929 cells. Similarly, we previously showed high cell adhesion and increased growth of such materials for bone marrow and adipose tissue-derived mesenchymal stem cells $[8,11,21$, 45]. Presence of proteoglycans, laminin, fibronectin and collagens within AM matrix endow an excellent cell attachment to this membrane [10]. As we reported previously, decellularisation process does not affect the cell adhesion of mesenchymal stem cells to AM [11]. According to this and our previous studies [8, 11, 21, 23], both AM and AM/SF offer desirable cell adhesion. 
Such favourable cell adhesion makes it a promising delivery system in tissue engineering applications

\subsubsection{Long-term cell viability and cytotoxicity}

The evaluation of the AM/ESF as potential matrix for the viability of the AT-MSCs was carried out based on the survival of the cells in reduced tetrazolium salt solution and formation of the crystals within their mitochondria. Determination of the cell viability (Fig. 6b) revealed that neither AM nor AM/ESF affected the viability of the AT-MSCs after specific incubation intervals. The results were compared to the $100 \%$ cell viability (independent sample $t$-test, $p>0.05)$.

The cytotoxicity of the samples on the AT-MSCs was evaluated by lactate dehydrogenase (LDH) specific activity assay. No cytotoxicity of the AM and AM/ESF membranes on the growth of AT-MSCs was detected (Fig. 6b). These results are consistent with the earlier relevant observations $[8,21,46-48]$.

\subsection{Angiogenic property of AM/ESF}

The AT-MSCs were seeded on the decellularised AM and AM/ESF membranes and incubated in a humidified atmosphere of $5 \% \mathrm{CO}_{2}$ and $95 \%$ air for 7 days. After specific time, the cells were evaluated for their expression of VEGFa and bFGF by real-time PCR and immunostaining. The results show that the post-injury neovascularization occurs during 7-14 days of healing depending on the severity of the wounds. IL-1 $\beta$, FGF, VEGFa and VEGFR2 are reported to be the most important factors involved in angiogenesis. It is reported that bFGF secreted during the 
first 3 days of wound repair, whereas VEGF may have a critical role in angiogenesis during days 4-7 post-injury $[49,50]$. In this study, we aimed to show whether the AM/ESF membrane can accelerate secretion of these angiogenic cytokines in vitro during first days of healing.

\subsubsection{Real-time PCR}

The angiogenic property of AM is debatable. It was reported that AM possesses anti-angiogenic properties when was implanted by its epithelial side [51]. Fast neovascularization during the first hours of wound healing might remarkably decrease local hypoxia and subsequently accelerate healing process [52-54]. Various biomaterials were investigated for acceleration of the angiogenesis within damaged area $[55,56]$. The angiogenic property of silk fibroin was reported by many $[36,57]$. AT-MSCs accelerate neovascularization through secretion of a variety of angiogenesis factors such as VEGFa, bFGF, IL-1b and others $[32,42]$. In this study, we showed that the AM/ESF significantly increased the expression levels of VEGFa and bFGF in AT-MSCs after 7 days when compared to AM alone and control $(\mathrm{p} \leq 0.05)$ (Fig. 7a). Our findings indicate the enhanced the angiogenesis in vitro of the ESF coated over the AM.

\subsubsection{Immunostaining}

Angiogenesis of the AM/ESF on the AT-MSCs was evaluated by immunostaining of VEGFa and bFGF (Fig. 7b). The cells expressing the angiogenesis factors are reported (Fig. 7c). Immunostaining revealed increased expressions of VEGFa and bFGF in AT-MSCs (Fig. 7b). The results show more than $90 \%$ and $70 \%$ of the AT-MSCs expressed VEGFa and bFGF, 
respectively. These angiogenesis data are also confirmed by our real-time PCR results and additional studies [36, 57].

\section{Conclusion}

The human amniotic membrane (AM) is widely used as a skin substitute in thermal injuries. Yet, tt is not fully satisfactory. This stems from the fact that its fast biodegradation rate, low mechanical and insufficient angiogenesis characteristics aren't optimal. . In this study, we develop and fully characterize a 3D bi-layer artificial skin made from AM and electrospun nanofiberous silk fibroin (ESF). The AM/ESF bi-layer membrane shows improved mechanical properties and slower biodegradation rate when compared to AM alone. The ESF allows for AM to be maintained in its 3D structure by reducing the bio-absorption rate. Our 3D bi-layer scaffold induces the adipose-derived mesenchymal stem cells to up-regulate angiogenic factors such as VEGFa and bFGF. These results indicate that the 3D bi-layer AM/ESF scaffold offers an attractive alternative in the skin substitute research area. 


\section{Acknowledgement}

We express our sincere thanks to Dr. Nariman Mosaffa and Dr. Mohammad Salehi for providing helpful comments on this work. SC Kundu presently holds an ERA Chair Full Professor position at the 3B's Research Group, University of Minho, Portugal, supported by the European Union Framework Programme for Research and Innovation Horizon 2020 under grant agreement $\mathrm{n}^{\mathrm{o}}$ 668983 - FoReCaST.

\section{Authors' contributions}

M.G., A.M.S. and A.S conceived and designed the study. M.G., A.S and H.G. performed the experiments. M.G., A.S., H.G. and A.M.S. analyzed the data. M.G., A.S., A.M.S., H.G., M.D.O., interpreted the results. M.G., M.M., A.M.S. and A.M.U. prepared the manuscript. M.G., A.M.S., M.M., A.M.U., J.G.H., S.C.K. and R.L.R reviewed during the preparation of manuscript and revised the manuscript.

\section{Disclosure}

The authors declare no conflict of interest both in terms of financial and publication of this work. All authors approved the final version of the manuscript. 


\section{References}

[1] Groeber F, Holeiter M, Hampel M, Hinderer S, Schenke-Layland K. Skin tissue engineering - in vivo and in vitro applications. Advanced drug delivery reviews, 2011; 63: 352-366.

[2] Chiang RS, Borovikova AA, King K, Banyard DA, Lalezari S, Toranto JD, Paydar KZ, Wirth GA, Evans GR, Widgerow AD. Current concepts related to hypertrophic scarring in burn injuries. Woúnd Repair and Regeneration, 2016; 24: 466-477.

[3] Pourchet LJ, Thepot A, Albouy M, Courtial EJ, Boher A, Blum LJ, Marquette CA. Human Skin 3D Bioprinting Using Scaffold-Free Approach. Advanced Healthcare Materials, 2016.

[4] Yu J, Huang TR, Lim ZH, Luo R, Pasula RR, Liao LD, Lim S, Chen CH. Production of hollow bacterial cellulose microspheres using microfluidics to form an injectable porous scaffold for wound healing. Advanced healthcare materials, 2016; 5: 2983-2992.

[5] Gilmartin DJ, Alexaline MM, Thrasivoulou C, Phillips AR, Jayasinghe SN, Becker DL. Integration of Scaffolds into Full-Thickness Skin Wounds: The Connexin Response. Advanced healthcare materials, 2013; 2: 1151-1160.

[6] Mamede A, Carvalho M, Abrantes A, Laranjo M, Maia C, Botelho M. Amniotic membrane: from structure and functions to clinical applications. Cell and tissue research, 2012; 349: 447-458.

[7] Gholipourmalekabadi M, Bandehpour M, Mozafari M, Hashemi A, Ghanbarian H, Sameni M, Salimi M, Gholami M, Samadikuchaksaraei A. Decellularized human amniotic membrane: more is needed for an efficient dressing for protection of burns against antibiotic-resistant bacteria isolated from burn patients. Burns, 2015; 41: 1488-1497.

[8] Gholipourmalekabadi M, Sameni M, Radenkovic D, Mozafari M, Mossahebi-Mohammadi M, Seifalian A. Decellularized human amniotic membrane: how viable is it as a delivery system for human adipose tissuederived stromal cells? Cell proliferation, 2016; 49: 115-121.

[9] Colocho G, Graham WP, Greene AE, Matheson DW, Lynch D. Human amniotic membrane as a physiologic wound dressing. Archives of Surgery, 1974; 109: 370-373.

[10] Niknejad H, Peirovi H, Jorjani M, Ahmadiani A, Ghanavi J, Seifalian AM. Properties of the amniotic membrane for potential use in tissue engineering. Eur Cells Mater, 2008; 15: 88-99. 
Gholipourmalekabadi M, Mozafari M, Salehi M, Seifalian A, Bandehpour M, Ghanbarian H, Urbanska AM, Sameni M, Samadikuchaksaraei A, Seifalian AM. Development of a cost-effective and simple protocol for decellularization and preservation of human amniotic membrane as a soft tissue replacement and delivery system for bone marrow stromal cells. Advanced healthcare materials, 2015; 4: 918-926.

[12] Ling S, Li C, Jin K, Kaplan DL, Buehler MJ. Liquid Exfoliated Natural Silk Nanofibrils: Applications in Optical and Electrical Devices. Advanced Materials, 2016.

[13] Han H, Ning H, Liu S, Lu Q, Fan Z, Lu H, Lu G, Kaplan DL. Silk Biomaterials with Vascularization Capacity. Advanced Functional Materials, 2016; 26: 421-432.

[14] Kanokpanont S, Damrongsakkul S, Ratanavaraporn J, Aramwit P. Physico-chemical properties and efficacy of silk fibroin fabric coated with different waxes as wound dressing. International journal of biological macromolecules, 2013; 55: 88-97.

[15] Shahverdi S, Hajimiri M, Esfandiari MA, Larijani B, Atyabi F, Rajabiani A, Dehpour AR, Gharehaghaji AA, Dinarvand R. Fabrication and structure analysis of poly (lactide-co-glycolic acid)/silk fibroin hybrid scaffold for wound dressing applications. International journal of pharmaceutics, 2014; 473: 345-355.

[16] Guang S, An Y, Ke F, Zhao D, Shen Y, Xu H. Chitosan/silk fibroin composite scaffolds for wound dressing. Journal of Applied Polymer Science, 2015; 132.

[17] Bellas E, Lo TJ, Fournier EP, Brown JE, Abbott RD, Gil ES, Marra KG, Rubin JP, Leisk GG, Kaplan DL. Injectable silk foams for soft tissue regeneration. Advanced healthcare materials, 2015; 4: 452-459.

[18] Kasoju N, Bora U. Silk fibroin in tissue engineering. Advanced healthcare materials, 2012; 1: 393-412.

[19] Wu J, Zheng Z, Li G, Kaplan DL, Wang X. Control of silk microsphere formation using polyethylene glycol (PEG). Acta biomaterialia, 2016.

[20] World MAGA. World Medical Association Declaration of Helsinki: ethical principles for medical research involving human subjects. Journal international de bioéthique= International journal of bioethics, 2004; 15: 124.

[21] Gholipourmalekabadi M, Mozafari M, Bandehpour M, Salehi M, Sameni M, Caicedo HH, Mehdipour A, Hamidabadi HG, Samadikuchaksaraei A, Ghanbarian H. Optimization of nanofibrous silk fibroin scaffold as a delivery system for bone marrow adherent cells: in vitro and in vivo studies. Biotechnology and applied biochemistry, 2015; 62: 785-794. 
[22] Um IC, Kweon HY, Lee KG, Park YH. The role of formic acid in solution stability and crystallization of silk protein polymer. International journal of biological macromolecules, 2003; 33: 203-213.

[23] Gholipourmalekabadi M, Mozafari M, Bandehpour M, Sameni M, Ghanbarian H. How ethanol treatment affects the physico-chemical and biological characteristics of silk fibroin nanofibrous scaffolds.

[24] Yucel T, Cebe P, Kaplan DL. Structural Origins of Silk Piezoelectricity. Advaneed functional materials, 2011;21: 779-785.

[25] Vepari C, Kaplan DL. Silk as a biomaterial. Progress in polymer science, 2007; 32: 991-1007.

[26] Mobini S, Solati-Hashjin M, Peirovi H, Osman NAA, Gholipourmalekabadi M, Barati M, Samadikuchaksaraei A. Bioactivity and biocompatibility studies on silk-based scaffold for bone tissue engineering. Journal of Medical and Biological Engineering, 2013; 33: 207-214.

[27] Hashemi SM, Hassan ZM, Pourfathollah AA, Soudi S, Shafiee A, Soleimani M. Comparative immunomodulatory properties of adipose-derived mesenchymal stem cells conditioned media from BALB/c, C57BL/6, and DBA mouse strains. Journal of cellular biochemistry, 2013; 114: 955-965.

[28] Alvarez DF, Helm K, DeGregori J, Roederer M, Majka S. Publishing flow cytometry data. American Journal of Physiology-Lung Cellular and Molecular Physiology, 2010; 298: L127-L130.

[29] Banas A, Teratani T, Yamamoto Y, Tokuhara M, Takeshita F, Quinn G, Okochi H, Ochiya T. Adipose tissue-derived mesenchymal stem cells as a source of human hepatocytes. Hepatology, 2007; 46: 219-228.

[30] Soleimani M, Nadri S. A protocol for isolation and culture of mesenchymal stem cells from mouse bone marrow. Nature protocols, 2009; 4: 102-106.

[31] Lorden ER, Miller KJ, Bashirov L, Ibrahim MM, Hammett E, Jung Y, Medina MA, Rastegarpour A, Selim MA, Leong KW. Mitigation of hypertrophic scar contraction via an elastomeric biodegradable scaffold. Biomaterials, 2015; 43: 61-70.

[32] Park I-S, Chung P-S, Ahn JC. Enhanced angiogenic effect of adipose-derived stromal cell spheroid with low-level light therapy in hind limb ischemia mice. Biomaterials, 2014; 35: 9280-9289.

[33] Bojnordi MN, Movahedin M, Tiraihi T, Javan M, Hamidabadi HG. Oligoprogenitor cells derived from spermatogonia stem cells improve remyelination in demyelination model. Molecular biotechnology, 2014; 56:387-393. 
[34] Riau AK, Beuerman RW, Lim LS, Mehta JS. Preservation, sterilization and de-epithelialization of human amniotic membrane for use in ocular surface reconstruction. Biomaterials, 2010; 31: 216-225.

[35] Vasconcelos A, Gomes AC, Cavaco-Paulo A. Novel silk fibroin/elastin wound dressings. Acta Biomaterialia, 2012; 8: 3049-3060.

[36] Yan S, Zhang Q, Wang J, Liu Y, Lu S, Li M, Kaplan DL. Silk fibroin/chondroitin sulfate/hyaluronic acid ternary scaffolds for dermal tissue reconstruction. Acta biomaterialia, 2013; 9:6771-6782.

[37] Ma DH-K, Lai J-Y, Cheng H-Y, Tsai C-C, Yeh L-K. Carbodiimide cross-linked amniotic membranes for cultivation of limbal epithelial cells. Biomaterials, 2010; 31: 6647-6658.

[38] Spoerl E, Wollensak G, Reber F, Pillunat L. Cross-linking of human amniotic membrane by glutaraldehyde. Ophthalmic research, 2004; 36: 71-77.

[39] Jones KS. Effects of biomaterial-induced inflammation on fibrosis and rejection. In: ed.^eds., Seminars in immunology. Elsevier, 2008; pp. 130-136.

[40] Velnar T, Bailey T, Smrkolj V. The wound healing process: an overview of the cellular and molecular mechanisms. Journal of International Medical Research, 2009; 37: 1528-1542.

[41] Posten W, Wrone DA, Dover JS, Arndt KA, Silapunt S, Alam M. Low-level laser therapy for wound healing: mechanism and efficacy. Dermatologic surgery, 2005; 31: 334-340.

[42] Shingyochi Y, Orbay H, Mizuno H. Adipose-derived stem cells for wound repair and regeneration. Expert opinion on biological therapy, 2015; 15; 1285-1292.

[43] Vladkova TG. Surface engineered polymeric biomaterials with improved biocontact properties. International Journal of polymer science, 2010; 2010.

[44] Park YR, Ju HW, Lee JM, Kim D-K, Lee OJ, Moon BM, Park HJ, Jeong JY, Yeon YK, Park CH. Threedimensional electrospun silk-fibroin nanofiber for skin tissue engineering. International Journal of Biological Macromolecules, 2016.

[45] Gholipourmalekabadi M, Mozafari M, Gholipourmalekabadi M, Nazm Bojnordi M, Hashemi-soteh MB, Salimi M, Rezaei N, Sameni M, Samadikuchaksaraei A, Ghasemi Hamidabadi H. In vitro and in vivo evaluations of three-dimensional hydroxyapatite/silk fibroin nanocomposite scaffolds. Biotechnology and applied biochemistry, 2015; 62: 441-450. 
[46] Collins AM, Skaer NJ, Gheysens T, Knight D, Bertram C, Roach HI, Oreffo RO, Von-Aulock S, Baris T, Skinner J. Bone-like Resorbable Silk-based Scaffolds for Load-bearing Osteoregenerative Applications. Advanced Materials, 2009; 21: 75-78.

[47] Wilshaw S-P, Kearney J, Fisher J, Ingham E. Biocompatibility and potential of acellular human amniotic membrane to support the attachment and proliferation of allogeneic cells. Tissue Engineering Part A, 2008; 14: $463-472$.

[48] Ju HW, Lee OJ, Lee JM, Moon BM, Park HJ, Park YR, Lee MC, Kim SH, Chao JR, Ki CS. Wound healing effect of electrospun silk fibroin nanomatrix in burn-model. International journal of biological macromolecules, 2016; 85: 29-39.

[49] Tonnesen MG, Feng X, Clark RA. Angiogenesis in wound healing. In: ed.^eds., Journal of Investigative Dermatology Symposium Proceedings. Elsevier, 2000; pp. 40-46.

[50] Bodnar RJ. Chemokine regulation of angiogenesis during wound healing. Advances in wound care, 2015; 4: 641-650.

[51] Niknejad H, Paeini-Vayghan G, Tehrani F, Khayat-Khoei M, Peirovi H. Side dependent effects of the human amnion on angiogenesis. Placenta, 2013; 34: 340-345.

[52] Price R, Anthony E, Myers S, Navsaria H. Tissue engineering for skin transplantation. Biomed. Eng, 2008; 2: $507-532$.

[53] Clark RA, Ghosh K, Tonnesen MG. Tissue engineering for cutaneous wounds. Journal of Investigative Dermatology, 2007; 127: 1018-1029.

[54] Chen H, Jia P, Kang H, Zhang H, Liu Y, Yang P, Yan Y, Zuo G, Guo L, Jiang M. Upregulating Hif-1 $\alpha$ by Hydrogel Nanofibrous Scaffolds for Rapidly Recruiting Angiogenesis Relative Cells in Diabetic Wound. Advanced healthcare materials, 2016.

[55] Höckel M, Schlenger K, Doctrow S, Kissel T, Vaupel P. Therapeutic angiogenesis. Archives of Surgery, 1993; 128: 423-429.

[56] Shan Y-H, Peng L-H, Liu X, Chen X, Xiong J, Gao J-Q. Silk fibroin/gelatin electrospun nanofibrous dressing functionalized with astragaloside IV induces healing and anti-scar effects on burn wound. International journal of pharmaceutics, 2015; 479: 291-301. 


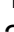

2

4

5

6

7

8

10

11

12

13

14

15

16

17

18

19

20

21

22

23

24

25

26

27

28

29

30

31

32

33

34

35

36

37

38

39

40

41

42

43

44

45

46

47

48

49

50

51

52

53

54

55

56

57

58

59

60
[57] Kijanska M, Marmaras A, Hegglin A, Kurtcuoglu V, Giovanoli P, Lindenblatt N. In vivo characterization of the integration and vascularization of a silk-derived surgical scaffold. Journal of Plastic, Reconstructive \& Aesthetic Surgery, 2016.

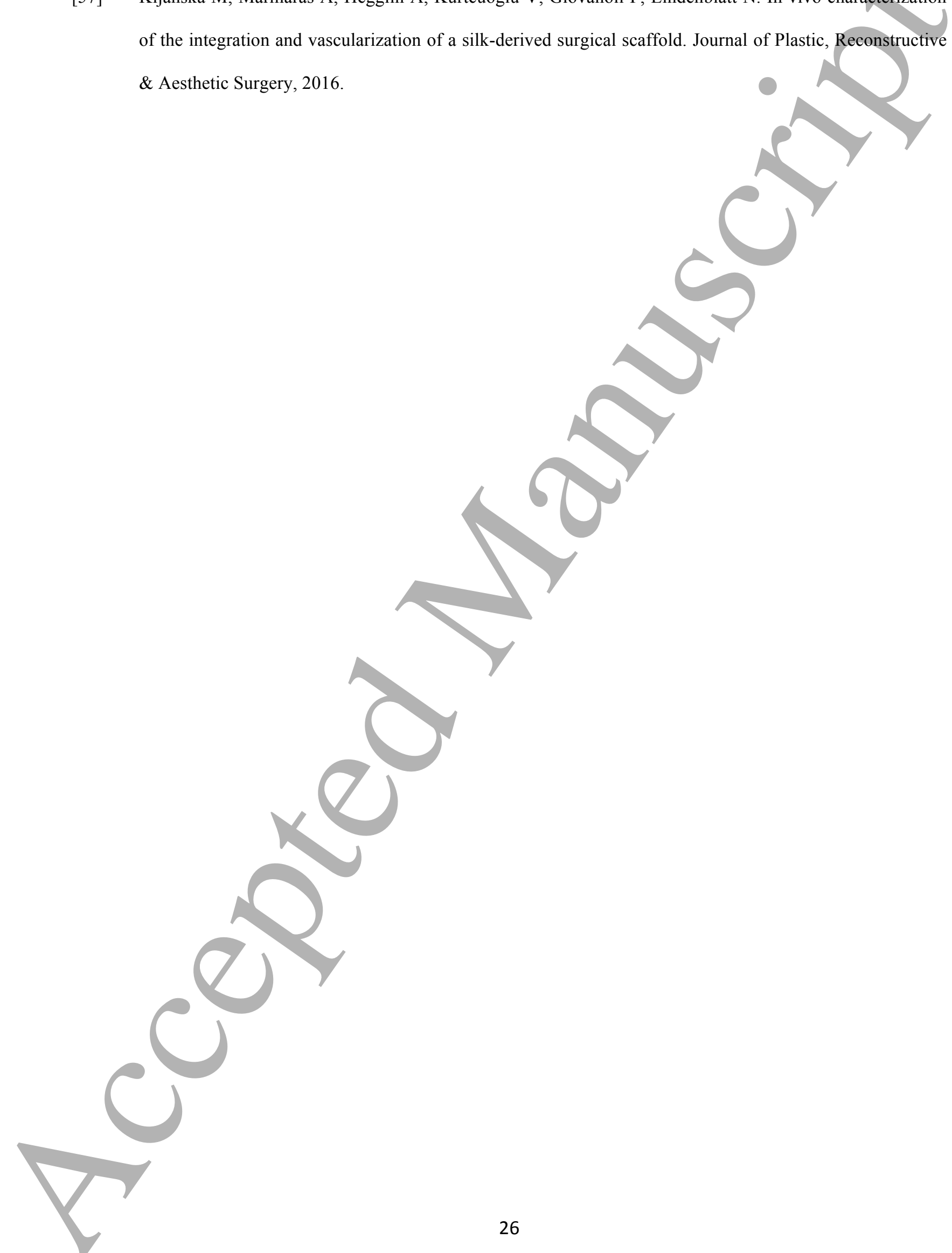




\section{Figure captions:}

Figure 1. Schematic preparation of the bi-layer artificial skin preparation. dAM: decellularised human amniotic membrane; ECs: epithelial cells; AM: human amniotic membrane; MSCs: mesenchymal stem cells; ESF: nanofibrous silk fibroin; SF: silk fibroin.

Figure 2. ${ }^{13} \mathrm{C}-\mathrm{NMR}$ spectra of the regenerated silk fibroin (SF) in formic acid at $0-200 \mathrm{ppm}$ (a) and 150-200 ppm (b). The distinctive peaks are appeared at $16.9 \mathrm{ppm}$ (C $\beta$ of Ala), 43.1 (C $\alpha$ of Gly) and 50.2 ( $\mathrm{C} \alpha$ of Ala) in the SF/FA solution. (c) FTIR spectra of SF before and after treatment with $70 \%$ ethanol for $1 \mathrm{~h}$. The results confirmed the $\beta$-sheet conformational transition of the silk fibroin.

Figure 3. Morphology of the membranes (a) SEM micrographs of the human amniotic membrane (AM), AM/electrospun nanofibrous silk fibroin (ESF) $(20 \mathrm{~min}$ and $3 \mathrm{~h}$ electrospinning) before and after treatment with ethanol as well as tilt view SEM image of the AM/ESF. Black and white arrows indicate ESF and AM, respectively. EUT: Ethanol-untreated, ET: Ethanol-treated. (b) Fiber diameter distribution in EUT and ET samples.

Figure 4. In vitro degradation time (\% mass loss) of the samples in PBS and lysozyme solutions during 14-days treatment.

Figure 5. Characterization of AT-MSCs. (a) Flow cytometry analysis of mesenchymal stem cells specific markers of CD44, CD73, CD90 and CD105 and hematopoietic lineage specific markers of CD34 and CD45. (b) Adipose tissue-derived stem cells (left) cultured in cell culture plate before differentiation induction, the Alizarin red stained cells after three weeks induction with osteogenic differentiation media (middle) and the Oil red stained cells after three weeks induction with adipogenic differentiation media (right). 
Figure 6. (a) SEM micrographs of the adipose tissue-derived mesenchymal stem cells (ATMSCs) cells cultured on AM/ESF before (EUT) and after (ET) ethanol treatment (b) Cell viability and cytotoxicity evaluated by MTT and LDH specific activity assays (c) Distribution of the AT-MSCs cultured on the AM, EUT-AM/ESF and ET-AM/ESF membranes after $72 \mathrm{~h}$ incubation in cell culture incubator.

Figure 7. In vitro angiogenesis. (a) Relative expression level of VEGFa and bFGF in adiposetissue derived mesenchymal stem cells (AT-MSCs) after 7 days culture on cell culture plate (control), AM and AM/ESF by real-time PCR. (b) Immunostaining of VEGFa and bFGF in ATMSCs, and (c) The percentage of the AT-MSCs expressing VEGFa and bFGF. * indicates significant difference with control. \# indicate significant difference with AM $(\mathrm{p} \leq 0.05)$. 


\section{Tables}

Table 1. Primers used in RT-PCR analysis.

\begin{tabular}{lllc}
\hline \multirow{2}{*}{ GENE NAME } & $\begin{array}{l}\text { ACCESSION } \\
\text { NUMBER }\end{array}$ & SEQUENCE & PRODUCT SIZE (BP) \\
\hline \multirow{2}{*}{ Beta actin } & NM_007393.5 & F: 5' CTTCTTGGGTATGGAATCCTG & 96 \\
& & R: 5' GTGTTGGCATAGAGGTCTTTAC & \\
\multirow{2}{*}{ VEGFa } & NM_001110268.1 & F: 5' TCGCTCCTCCACTTCTGAGG & 93 \\
& & R: 5' GGCCATTACCAGGCCTCTTC & \\
bFGF & NM_008006.2 & F: 5' CCGGTCACGGAAATACTCCA & 89 \\
& R: 5' CCTTCTGTCCAGGTCCCGTT & \\
\hline
\end{tabular}

Table 2. Mechanical properties of human amniotic membrane (AM) and the bi-layered AM/electrospun nanofibrous silk fibroin (ESF) scaffold. Freeze dried samples. *Significant difference.

Properties checked

AM

$\mathrm{AM} / \mathrm{ESF}$

$P$ value

Thickness $(\mu \mathrm{m})$

$97.0 \pm 8.2$

$127.0 \pm 6.7$

$\mathrm{P}<0.05^{*}$

Maximum load value (N)

$1.30 \pm 0.17$

$1.90 \pm 0.18$

$\mathrm{P}<0.05^{*}$

Suture retention strength $(\mathrm{mN})$

$512 \pm 63$

$692 \pm 31$

$\mathrm{P}<0.05^{*}$

Strain deflection at break $(\mathrm{mm})$

$7.30 \pm 0.49$

$8.50 \pm 0.33$

$\mathrm{P}<0.05^{*}$ 


\section{Figure 1}

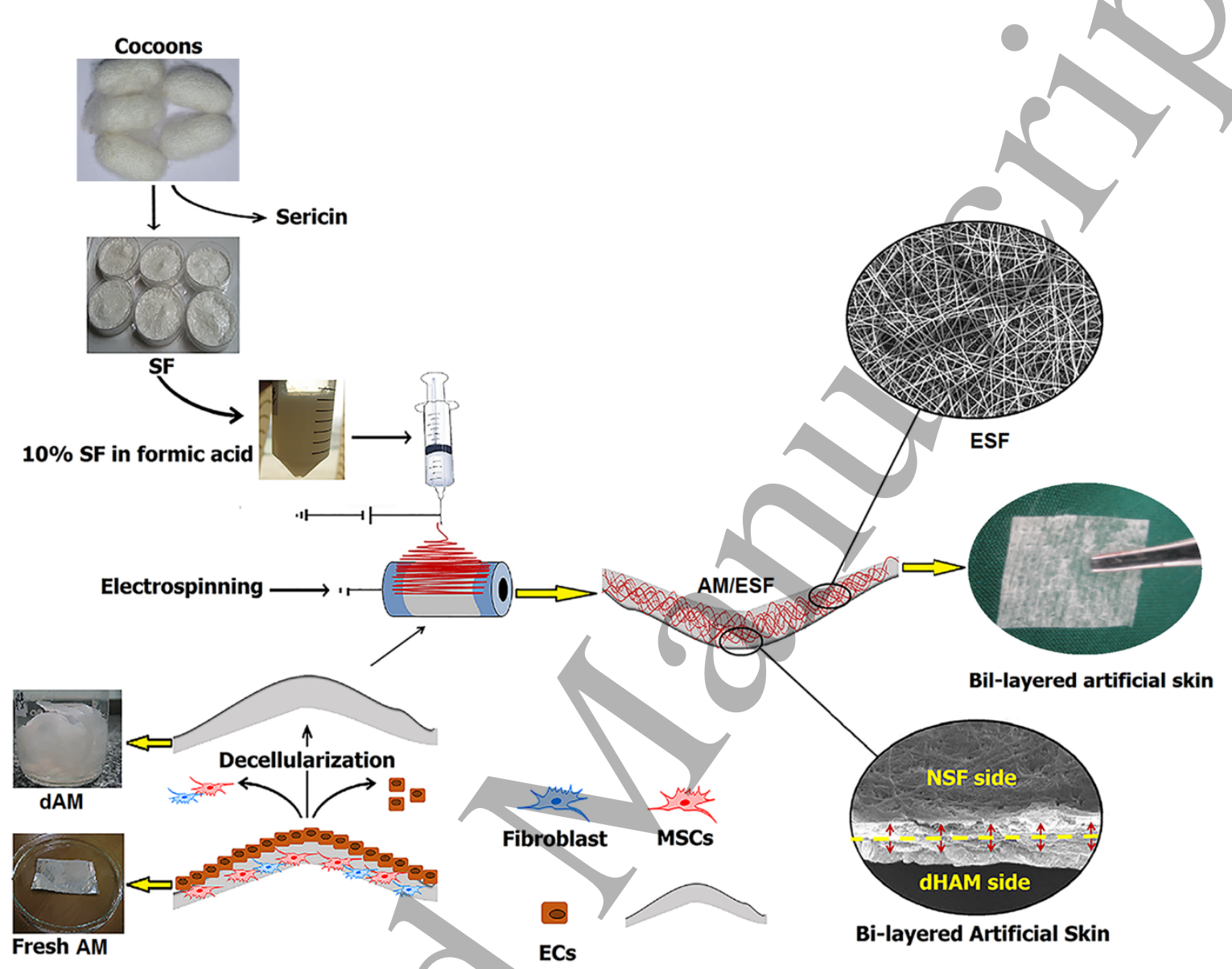


Figure 2

(b)

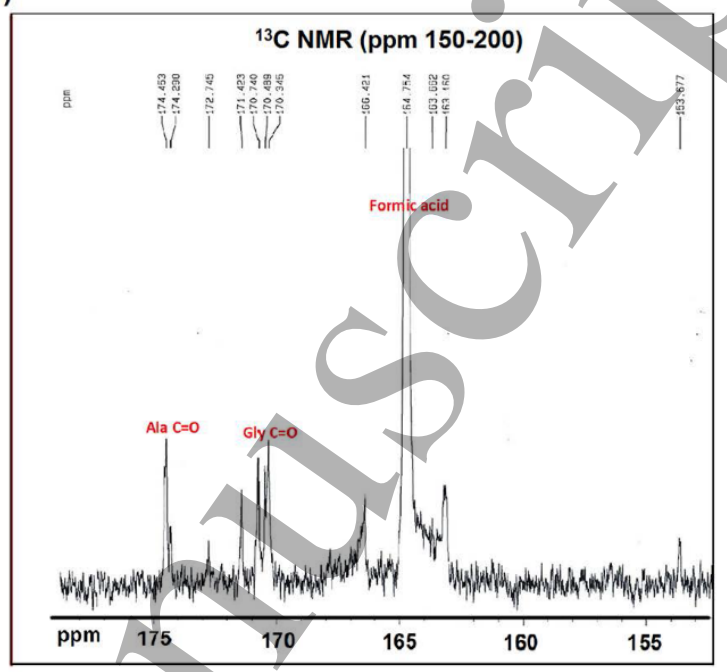

(a)

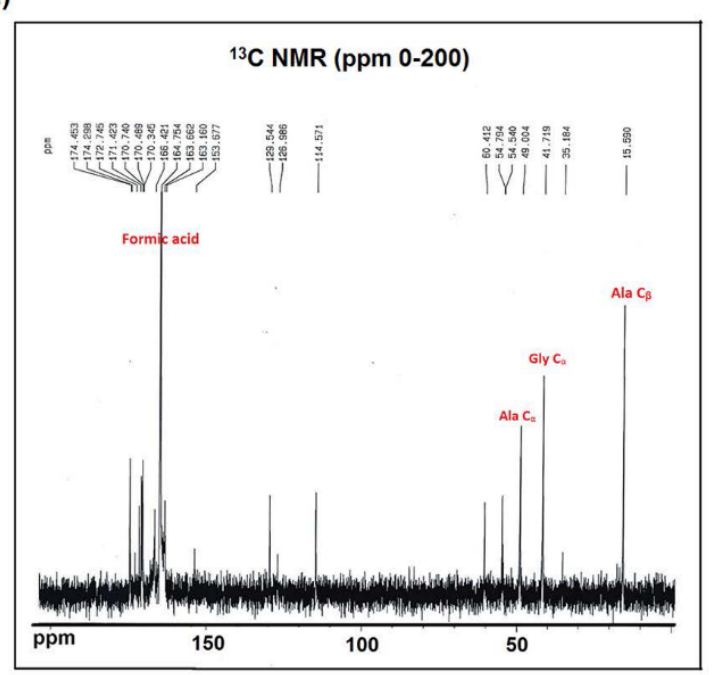

(c)

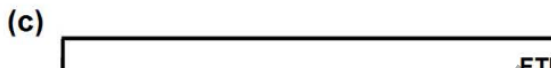

$\begin{array}{ll}8 & \\ 9 & \\ 10 \\ 11 \\ 12 \\ 13 \\ 14 \\ 15 \\ 16 \\ 17 \\ 18 \\ 19 \\ 20 \\ 21 \\ 22 \\ 23 \\ 24 \\ 25\end{array}$

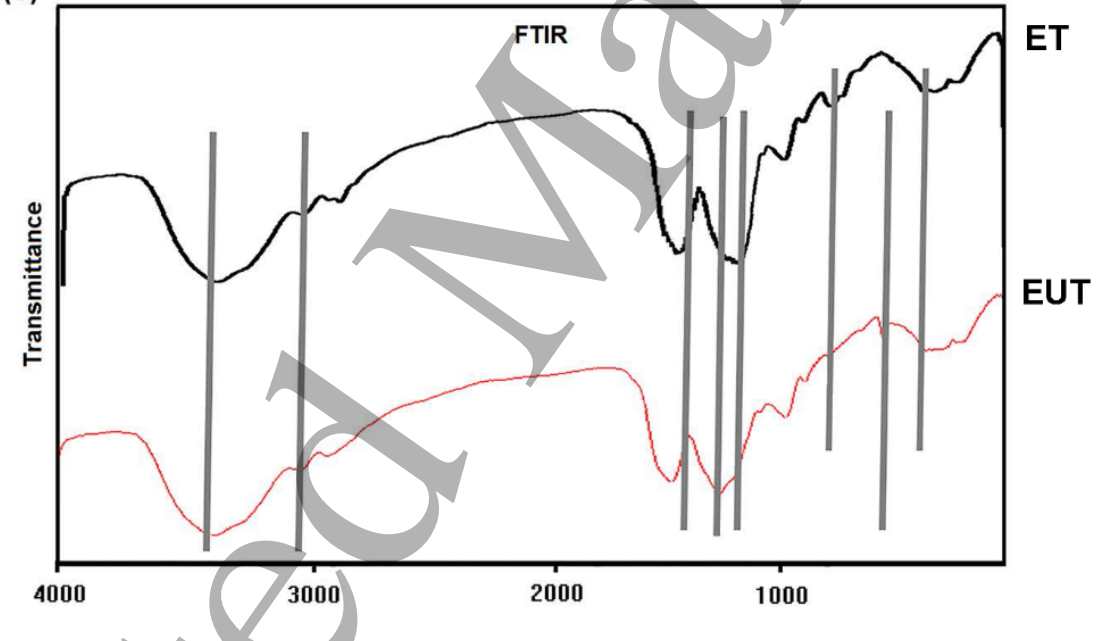

Wavenumber $\left(\mathrm{cm}^{-1}\right)$ 


\section{Figure 3}

(a)
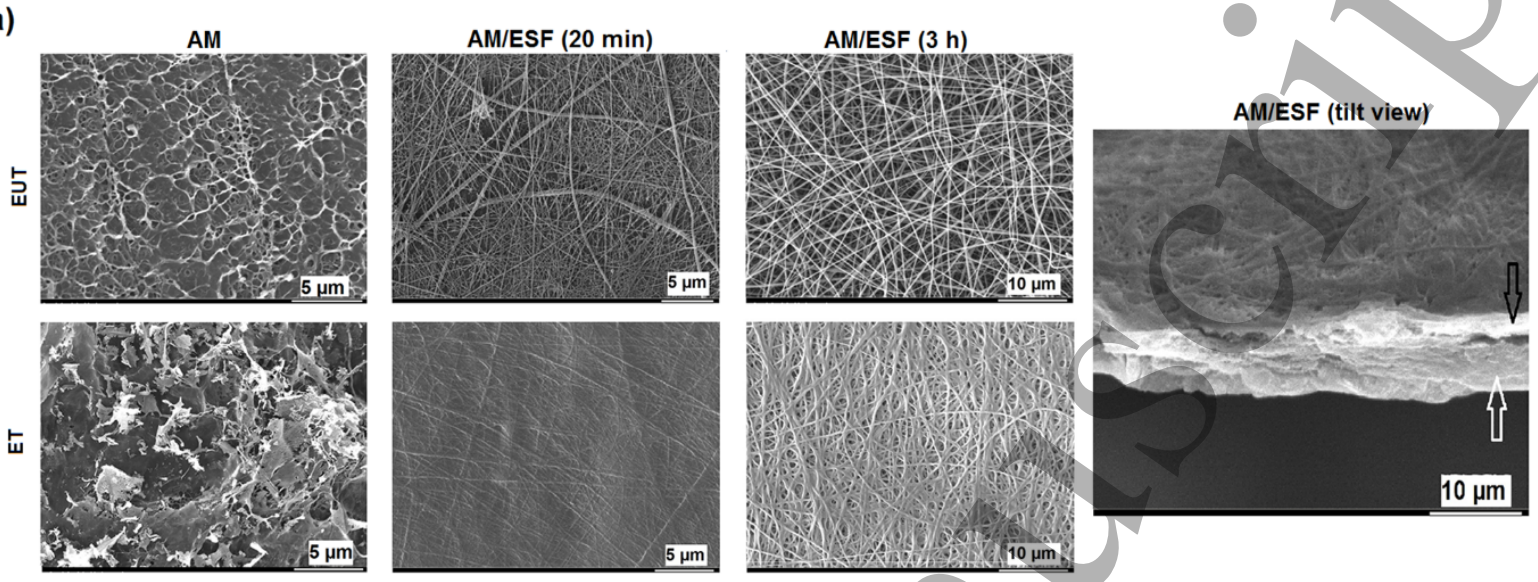

(b)
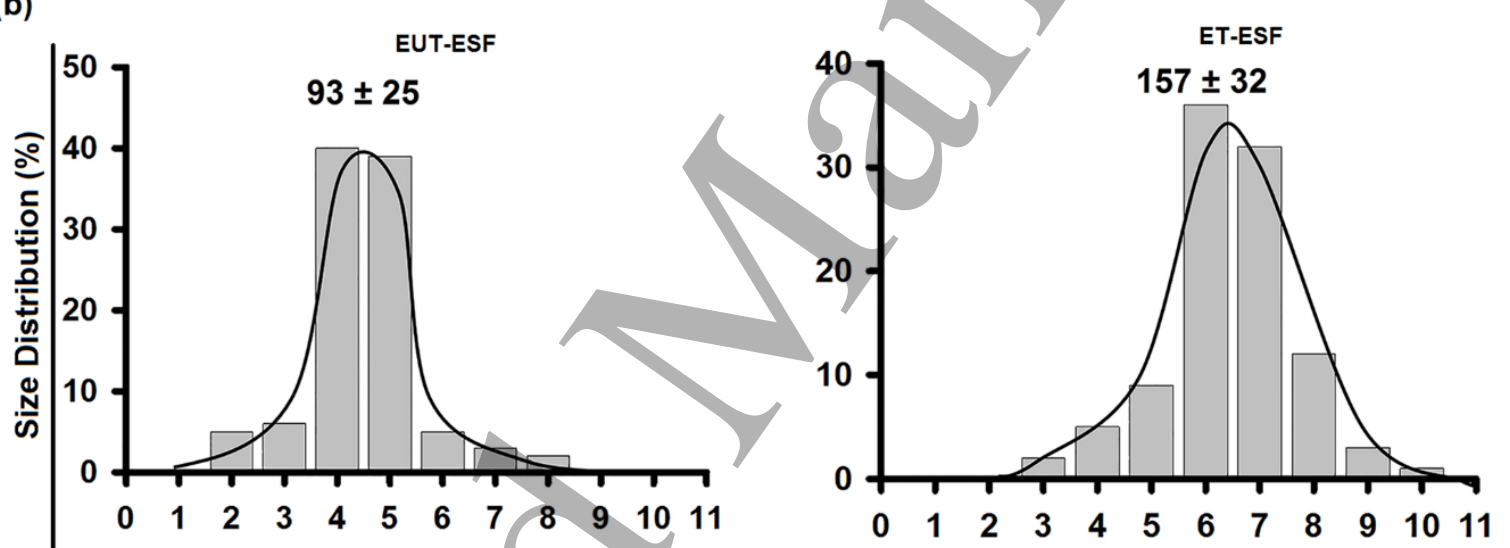

Fiber Diameter (nm) 


\section{Figure 4}

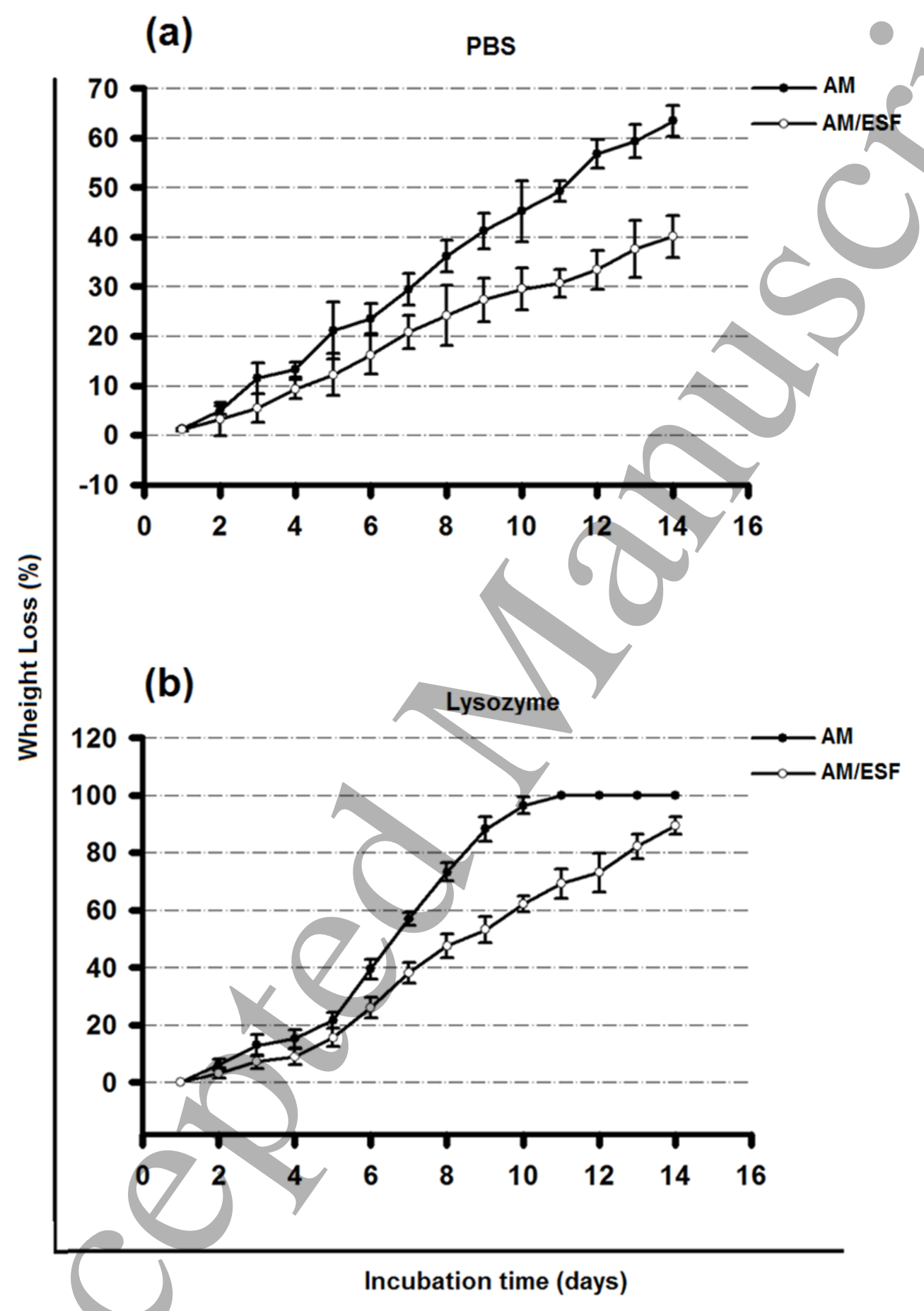




\section{Figure 5}

(a)
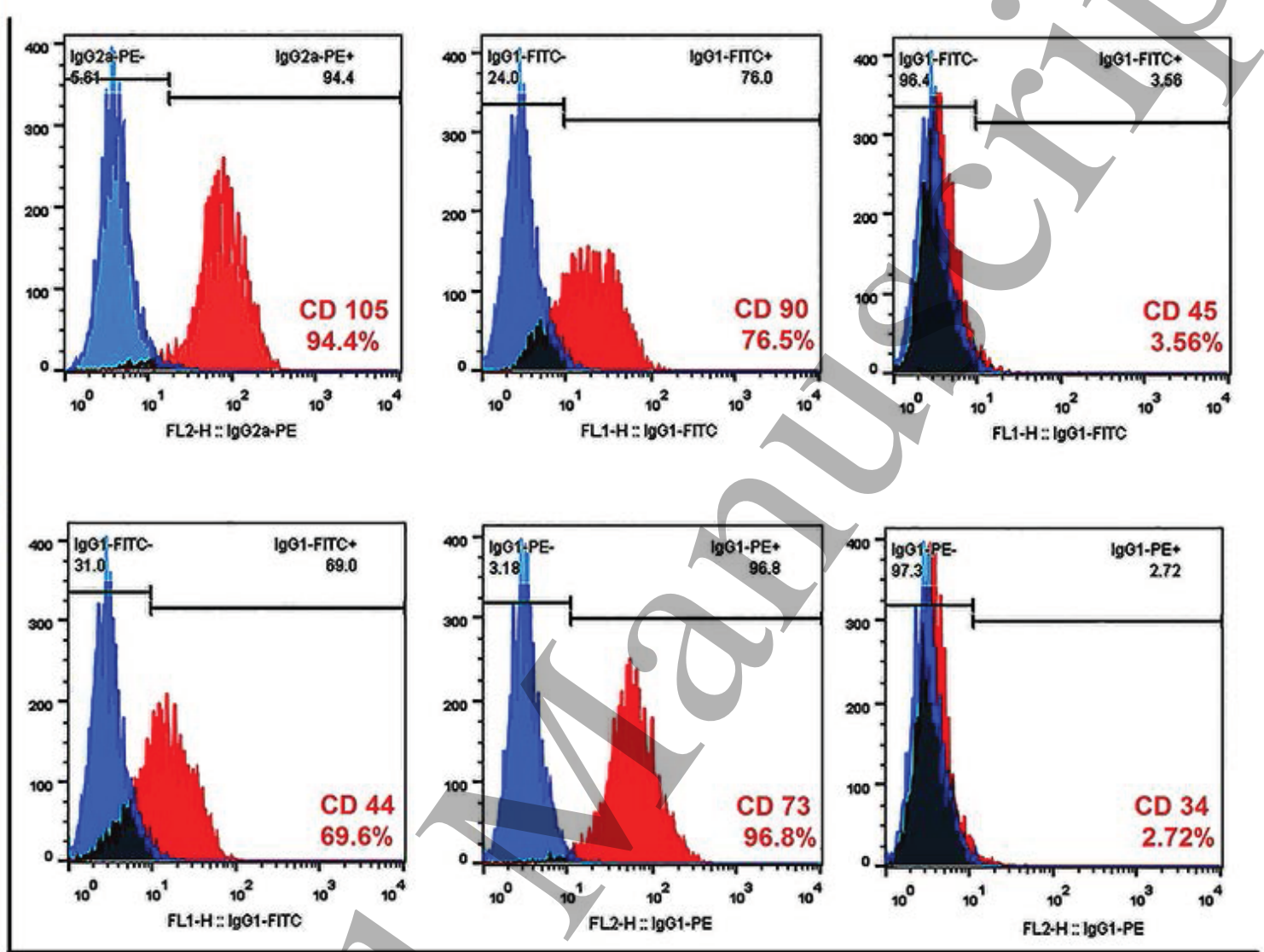

FL

(b)

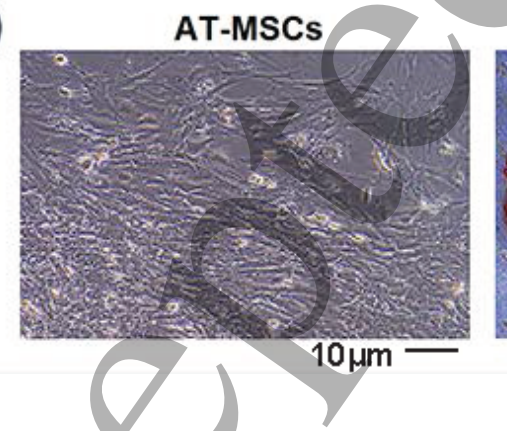

Alizarin Red

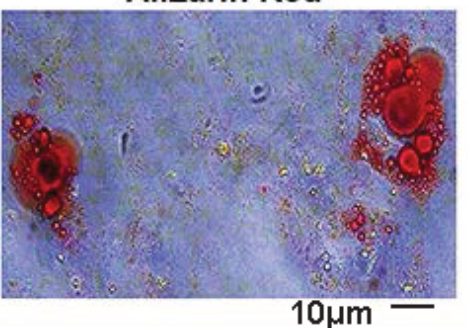

Oil Red

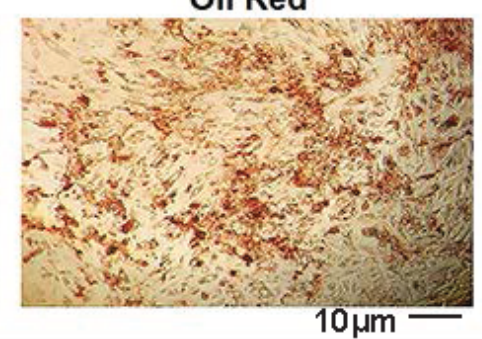




\section{Figure 6}

(a)

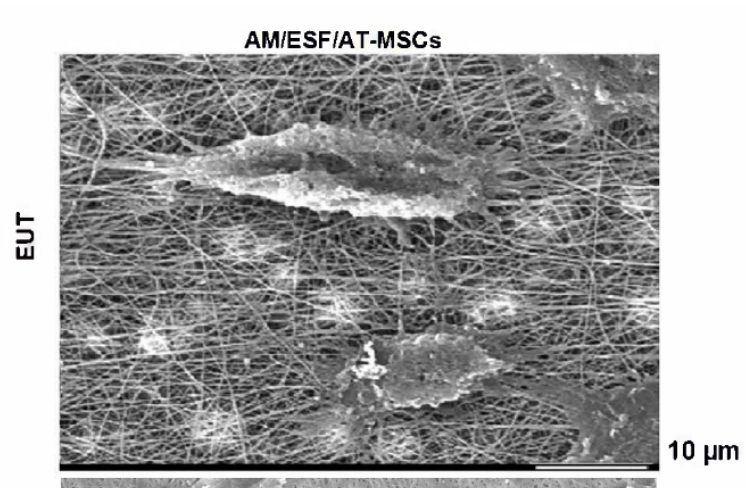

(c)

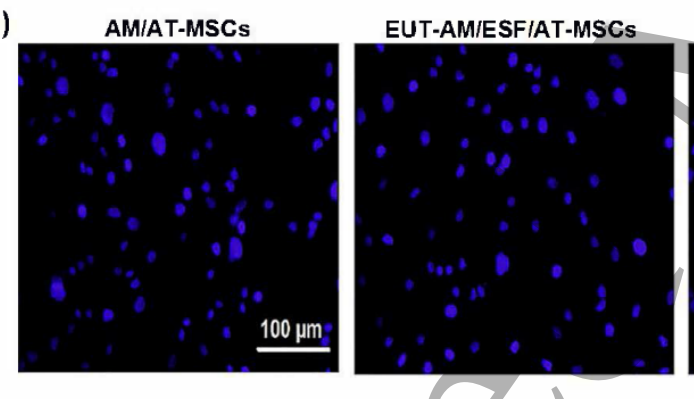

(b)
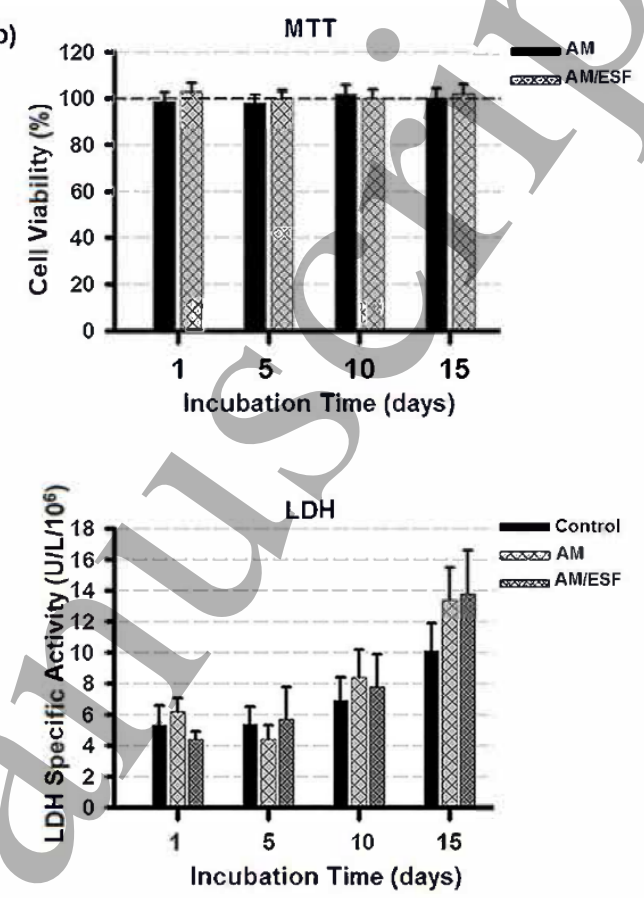

$10 \mu \mathrm{m}$
ET-AM/ESFIAT-MSCs

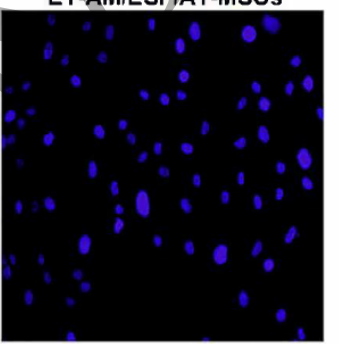

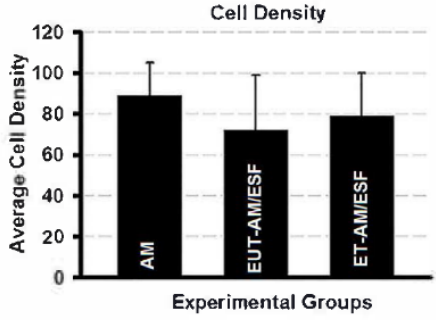




\section{Figure 7}

(a)

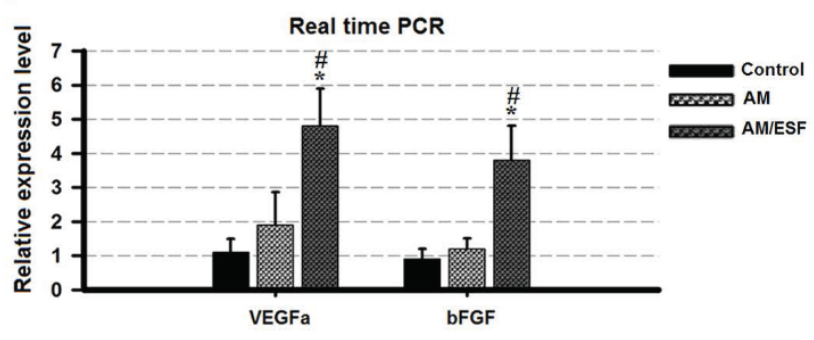

(b)
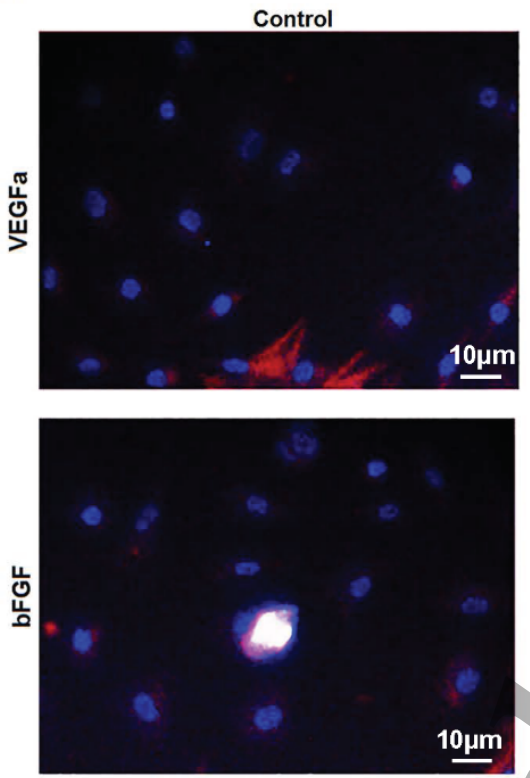

(c)

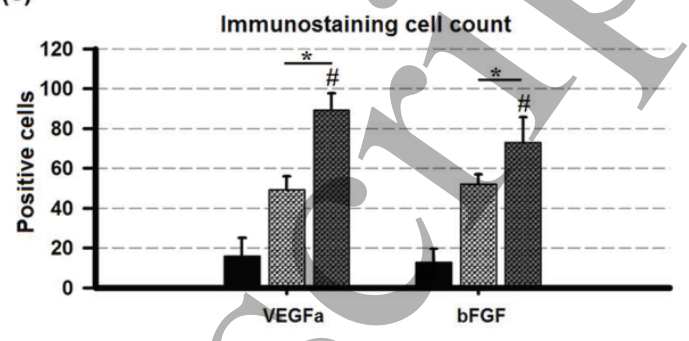

